\title{
Who Responds to Health, Environmental, and Economic Information about Local Food? Evidence from Connecticut Seafood Consumers
}

\author{
Yixing $\operatorname{Tian}^{1}$ \\ Rose Croog $^{2}$ \\ John Bovay ${ }^{3}$ \\ Anoushka Concepcion ${ }^{4}$ \\ Tessa L. Getchis ${ }^{5}$ \\ Miriah Russo Kelly ${ }^{6}$
}

${ }^{1}$ Graduate student, College of Economics and Management, China Agricultural University.

${ }^{2}$ Associate Research Analyst, Connecticut Department of Energy and Environmental Protection.

${ }^{3}$ Assistant Professor, Department of Agricultural and Applied Economics, Virginia Tech.

Corresponding author: bovay@,vt.edu. Twitter@JohnBovay.

${ }^{4}$ Assistant Extension Educator for Marine Aquaculture, Connecticut Sea Grant and Department of Extension, University of Connecticut.

${ }^{5}$ Senior Extension Educator, Connecticut Sea Grant and Department of Extension, University of Connecticut.

${ }^{6}$ Assistant Professor, Department of Environment, Geography \& Marine Sciences, Southern Connecticut State University. 


\title{
Who Responds to Health, Environmental, and Economic Information about Local Food? Evidence from Connecticut Seafood Consumers
}

\begin{abstract}
We designed and implemented a discrete choice experiment to assess how information about the health, environmental, and economic benefits of locally produced aquaculture products affect Connecticut consumers' willingness to pay (WTP) for products produced in the state, as compared with products from another state or another country. We find that information about local economic benefits tended to increase WTP for Connecticut-grown and -raised products, whereas information about health, safety, and the environment tended to decrease WTP for products from other regions. We also explore heterogeneous effects of the information treatments by respondent gender, education, and income.
\end{abstract}

Key words: Aquaculture, Choice Experiment, Clams, Information, Local food, Oysters, Seaweed, Shellfish, Willingness to pay, Seafood 


\section{Who Responds to Health, Environmental, and Economic Information about Local Food? Evidence from Connecticut Seafood Consumers}

\section{Introduction}

This paper assesses the effects of presenting consumers with information about the health, environmental, and economic benefits of aquaculture on willingness to pay (WTP) for seaweed and shellfish aquaculture products produced locally in Connecticut and in other locations. ${ }^{1}$ Unlike most previous studies that used choice experiments with a focus on product attributes and labeling, we also analyze the effects of information treatments on demand for local aquaculture products in Connecticut, and explore heterogeneous effects of these information treatments by gender, income, and education level.

The New England region was historically the center of U.S. oyster and clam culture, and Connecticut was once the top oyster-producing state (Connecticut Department of Agriculture, personal communication). According to the 2017 U.S. Census of Agriculture, Washington state and Virginia now produce more than half of all mollusks (by farm sales value) while New England produces about 15 percent. Until recently, Connecticut shellfish growers tended not to market their products locally, instead selling live, raw shellfish through seafood distributors (see, e.g., Getchis et al., 2020). Connecticut kelp farmers, representing a new aquaculture sector for the state, are racing to establish connections with buyers and creatively brand and promote

\footnotetext{
${ }^{1}$ Connecticut is the third-smallest U.S. state in area. No point is more than $100 \mathrm{~km}$ from the coast. The total area of the state is smaller than that of Beijing Municipality and 47 U.S. counties. Thus, assessing Connecticut consumers' WTP for food grown in the state is much like assessing WTP for "local food" for residents of other states and countries, but with more specificity than the term "local food".
} 
products before growers in other U.S. states establish market presence. ${ }^{2}$ As of 2020, there were 15 operations permitted to cultivate seaweed in the Long Island Sound off the coast of Connecticut (Robidoux and Chadsey, 2020).

This study provides evidence on how Connecticut producers and marketers of aquaculture products - and by extension, producers and marketers in other regions who are trying to sell their products as "local" - may stimulate demand by providing information. In particular, we find that informing consumers about the economic contributions of the aquaculture industry to the local economy boosts demand more than providing other types of information does. In addition to providing evidence on how locally produced clams and oysters may be better marketed, we provide evidence on Connecticut consumers' interest in seaweed products, which are essentially a niche product seen as novel by many consumers. Our research suggests that providing information about seaweed can help bolster consumer demand for seaweed products.

Consumers are often faced with detailed information about product-quality attributes such as the origin of the product, nutrition, and price. This paper contributes to our knowledge about consumers' valuation of aquaculture (seaweed and shellfish) products produced locally relative to those produced in other regions, and how their valuation of products may adjust when receiving additional information about the economic, health, and environmental benefits of the products. More importantly, we demonstrate heterogeneous effects of this information on different types of consumers' WTP for local products.

\footnotetext{
2 Source: Connecticut Department of Agriculture. Retrieved August 27, 2019, from https://portal.ct.gov/DOAG/News/2015/THE-STATE-OF-KELP--A-New-Sea-Vegetable-Industry-Is-Poised-for-Growth-if-TheseNew-Farmers-Can-Develo.
} 
The remainder of the paper is organized as follows. In the next section, we provide additional background and a review of the literature. Then, we describe the design of our discrete choice experiment. In the results section, we review estimates of demand parameters from a series of conditional logit models. We then review estimates of WTP by product, including estimated effects of the information treatments on WTP. We also provide evidence on heterogeneous responses of consumers by gender, education, and income. We then discuss how treatment effects differ depending on whether respondents stated that they already consume seaweed and shellfish. The final section synthesizes results and discusses directions for future research.

\section{Background}

U.S. consumers are demanding more locally or regionally produced foods (Feldmann \& Hamm, 2015). According to the most recent USDA Census of Agriculture (2017), about $8.1 \%$ of the value of agricultural products sold in Connecticut are sold directly to consumers, up from $5.5 \%$ in 2012 . Connecticut consumers spent about $4.8 \%$ of their total food budgets on Connecticut-grown food products in 2015 (Boehm \& Bovay, 2018). The COVID-19 pandemic has seriously impacted demand for seafood products, which are frequently consumed in restaurants, and also may have slowed supply chains for imported aquaculture products. In light of the economic stress facing aquaculture producers due to the pandemic (van Senten et al., 2021), growing consumer demand for local foods, and the development of policies promoting local food systems in Connecticut, it is important to track and estimate consumer preferences for locally produced aquaculture. 
A substantial body of research has found that consumers have a higher WTP for local food products (Printezis et al., 2019). A limited number of research articles have estimated WTP for locally produced seafood (Quagrainie et al., 2008, Fonner \& Sylvia, 2015, Kecinski et al., 2017; Shamshak et al., 2020) and local seafood with product integrity labels (Ropicki et al., 2010). Several other papers have analyzed consumer preferences for aquaculture products such as oysters (Kecinski et al., 2017; Li et al., 2017; Loose et al., 2013; Manalo \& Gempesaw, 1997; Thapa et al., 2015) and salmon (Alfnes et al., 2006; Holland \& Wessells, 1998; Roheim et al., 2012), and a broader array of aquaculture products (Bouchard et al., 2021). Ortega et al. (2014) found that American consumers had a higher WTP for domestic shrimp and tilapia products relative to imported Chinese or Thai products. Kuchler et al. (2010), however, found no change in demand for shrimp following the implementation of Country of Origin Labeling (COOL) standards in their analysis of Nielsen Homescan panel data, despite looking at a submarket that is typically more responsive to label changes: college-educated consumers.

Two studies closely resemble ours. Brayden et al. (2018) used a nationwide online survey to estimate consumers' WTP for products from their home state, versus unspecified U.S. origin and imported. The products included oysters, clams, mussels, scallops, and seaweed salad. They found that consumers are WTP more for products from their home state. Bi et al. (2016) examined the impact of information about health and nutritional benefits on demand for finfish and shellfish. They used a nutritional information treatment intended to provide product information similar to what is found on a nutritional label. This treatment resulted in an increase 
in marginal WTP for all seafood types they measured (shrimp, salmon, oysters, mahi-mahi, and grouper).

\section{Methodology}

Discrete choice experiments are widely employed in stated preference elicitation. This type of methodology is useful in a variety of disciplines in order to understand individual preferences across alternative goods, services, or policy actions (Louviere et al., 2010). Stated preference discrete choice experiments are designed to mimic real-world choice scenarios in a hypothetical situation (Ortega et al., 2014).

Discrete choice experiments have a theoretical basis in random utility theory (RUT) (Thurstone, 1927). Under RUT, $U_{i j n}$ represents the utility consumer $i$ obtains from choosing the $j$ th alternative in the $n$th choice situation (e.g., the $n$th question in a choice experiment). In accordance with RUT, and assuming that utility is a function of product attributes $X_{i j n}$, we have:

$$
U_{i j n}=\alpha X_{i j n}+\varepsilon_{i j n},
$$

where $\varepsilon_{i j n}$ is the unobservable and random component which is independent and identically distributed (i.i.d.). Specifically, researchers assume that consumers maximize their utility among all options available (McFadden, 1973). They then use regression analysis, conditioning on the attribute levels of all products offered, to predict how consumers' choices respond to changes in attribute levels or covariates representing differences in individual consumers' characteristics.

\subsection{Survey and question design}

In our study, we employed a survey instrument to measure the attitudes, behaviors, and preferences of Connecticut residents as related to shellfish and seaweed products. To obtain our 
sample, we contracted with Qualtrics to collect responses from a representative panel of Connecticut residents, which we found to be more cost-effective than other approaches such as intercept or mailed surveys. However, using a panel from a third party has potential drawbacks to consider. For instance, we do not necessarily know whether those who participate in onlinesurvey panels answer questionnaires differently than the general population would, especially since these individuals often engage in numerous studies at one time. ${ }^{3}$ Existing studies (e.g., Bartneck et al., 2015 and Casler et al., 2013) mostly support the validity of stated preference studies that rely on respondents recruited via online panels.

We solicited feedback about the clarity and organization of our draft survey from more than 20 members of the general public and subject matter experts. We also used this process to determine the expected time commitment for participants to complete the survey. In addition, during this phase, we received critical feedback on the wording of the questions. This was particularly useful to us because we had originally intended to vary product attributes across several dimensions (e.g., farm-raised versus wild-caught shellfish; canned versus fresh versus frozen; branded versus generic). Many respondents found such choice sets overwhelming, even though they routinely make shopping decisions faced with information about such attributes. Ultimately, we opted to improve accuracy of WTP estimates for the attribute that mattered most for our research question - production location — by varying only location and price within each product category. Although we do not have formal quantitative data on how the initial versions

\footnotetext{
${ }^{3}$ Qualtrics automatically disqualified respondents who finished the survey in less than $1 / 3$ of the average completion time.
} 
of the choice sets were perceived and processed, we suggest that future researchers consider the drawbacks of complicated choice sets, particularly as part of lengthy surveys. More work can be done to assess the effects of survey design on precision of WTP estimates.

We supplied the link to our survey to a Qualtrics Project Leader who distributed this survey to the registered Qualtrics survey-takers residing in Connecticut, with a goal of collecting 1,800 responses. ${ }^{4}$ Using a non-probability quota sample approach, the sample mirrored, to the best extent possible, the distribution of people based on gender, age, and income in Connecticut. ${ }^{5}$ These calculations relied on 2010 Census data. Upon completion, individual survey responses appeared on our UConn Qualtrics accounts in real time. In the end, we collected 1,756 responses.

\subsection{Experiment design}

We elicited respondents' willingness to pay (WTP) for Connecticut aquaculture products, relative to products from other states or countries, using a discrete-choice experiment. The basic outline of the experiment is as follows: Each respondent was asked to make four choices for each seafood product — that is, to state their preference for one of four similar products, or a none-ofthe-above option, 16 times in all for four products in the survey. Therefore, there are 7,024 observations for each product ( 4 choice occasions $\times 1,756$ respondents). Figure 1 presents a sample choice set. Table 1 gives details on the choice sets. ${ }^{6}$

\footnotetext{
${ }^{4}$ Considering each of the four products separately, each consumer was asked to make four sets of choices ( $\left.t=4\right)$ among four nonnull products $(\mathrm{a}=4)$ that have four attribute levels $(\mathrm{c}=4)$. We had nine treatment cells (two treatments and one control, and three subsets of the complete set of choice sets. The number of respondents per treatment cell should be at least $n=500 \mathrm{c} / \mathrm{ta}$, and perhaps as large as $n=1000 c / t a$, according to Orme (2010). Based on Orme (2010), we therefore needed a sample of 1,125 to 2,250 for analysis of consumers' choices with a survey of our complexity.

5 Table 2 presents information about the demographics of survey participants under each treatment.

6 We called or visited multiple local grocery stores and used a range of prices corresponding to the prices in those stores, in $\$ 1$ increments. If the range was smaller than $\$ 3$, we started from the lowest prices seen in the stores and increased the price from
} 
Our study's main contribution is that it deploys information treatments to gauge how knowledge of the products' health, environmental, and economic benefits interact with an individual's choices of shellfish and seaweed products. We used two information treatments and one control group, which received no treatments. The two treatments (T1 and T2; see figure 2) provide information about health and safety and the environmental benefits of aquaculture (T1), and the economic contribution of aquaculture to the Connecticut economy (T2).

The study's subset of seaweed and shellfish choices was generated by an efficient factorial design in SAS with respondents randomly assigned to three blocks of questions. We followed the orthogonal fractional factorial design approach (Green \& Srinivasan, 1990) by generating six subsets of all 256 possible choice sets in the full factorial design. ${ }^{7}$ We randomly assigned participants into one of 18 groups of about 100 participants each (12 of which received information treatments, and six of which served as control groups; two treatment groups and one control group for each subset of choice sets). The treatments were presented to respondents just prior to a set of 16 choice questions. Note that T1 and T2 were two separate treatments and that individuals saw only one of the two statements (or neither) randomly.

\subsection{Choice modeling}

By varying the prices across each of the four product types (i.e., production regions) and analyzing respondents' choices across the various iterations of the survey questions, we are able

there. We included China and Korea as production location options only because they are important sources of seaweed and shellfish - not because we were interested in public attitudes toward diplomacy.

7 As seen in table 1, each of the four products has four attribute levels (production location) and four price levels. Each of the four price levels could be associated with each of the four attribute levels. Thus, we the full factorial design has $4^{4}=256$ possible choice sets. 
to estimate WTP for Connecticut aquaculture products and WTP premiums for Connecticut aquaculture products relative to products from other states or countries. We analyzed respondents' choices using a conditional logit (CL) model (see Cameron and Trivedi, 2010). ${ }^{8}$

We expressed the CL model as:

$$
P\left(Y_{i n}=j\right)=\frac{\exp \left(\beta P_{i j n}+\gamma X_{i j n}\right)}{\sum_{k=1}^{5} \exp \left(\beta P_{i k n}+\gamma X_{i k n}\right)}
$$

where $Y_{\text {in }}$ indicates the option chosen (among $j=1, \ldots, 5$ ) by consumer $i$ in choice set $n$, $P_{i j n}$ is the price seen by consumer $i$ for option $j$ in choice set $n$, and the vector $\boldsymbol{X}$ includes binary variables for each of the four locations of production. ${ }^{9}$ In each choice set, consumers were presented with four options, which varied by price and production region, plus a "none of these" option with a price assumed to be zero. We also examine possible heterogeneity in preferences among men and women, participants with higher and lower income, and participants with more and less education, by breaking down the set all observations into these subsamples. In nearly all regression specifications, we include only individuals who indicated that they ate seaweed or shellfish (as appropriate), but we also run suites of regressions that include all respondents, and suites that exclude seaweed or shellfish consumers.

We estimate WTP for each product, under each treatment and for each subgroup of respondents, using the wtp command in Stata and construct the confidence intervals using the

\footnotetext{
8 The conditional logit model imposes the assumption of preference homogeneity across consumers. This assumption may be overly restrictive. We considered using the random-parameters logit model (also called mixed logit), which relaxes this assumption, but the maximum-likelihood estimation would not converge in Stata for any of the four product groups.

9 This conditional logit model is derived from a random utility function with the form $U_{i j n}=\beta P_{i j n}+\boldsymbol{\gamma} \boldsymbol{X}_{i j n}+\varepsilon_{i j n}$. In other words, the only attributes that enter consumers' utility function in our model are price and the location of production. Since the "none of these" option has a price of zero and no location of production, the utility associated with choosing "none of these" is normalized to zero. Thus, the WTP measures derived from this model should all be considered relative to the "none of these" option.
} 
Krinsky-Robb (1986) (parametric bootstrap) method with 10,000 repetitions. This command estimates confidence intervals for the WTP estimates generated from the ratio $W T P_{j}=-\gamma_{j} / \beta$, where $\gamma$ and $\beta$ are defined in equation (2) above.

\section{Results}

Appendix table A1 presents the estimated logit coefficients from a series of CL models in which all main regressors are interacted with treatment dummy variables. Appendix table A2 presents estimated logit coefficients from a second series of CL models in which control and treatment groups are analyzed separately. The regressions in appendix table A2 are used to estimate WTP for products from each state or country of origin, under each treatment. Estimates of WTP are shown in tables 3 through 6 for seaweed noodles, fresh seaweed, clams, and oysters, respectively. 95\% confidence intervals are shown in parentheses below each point estimate. Panel A of tables 3 through 6 shows the WTP estimates for all consumers who answered affirmatively to the questions "Do you eat seaweed?" and "Do you eat shellfish?" as appropriate, under each treatment and the control. Panels B through G of tables 3 through 6 further break down estimates of WTP by respondent gender, education, and income. Panel H of tables 3 through 6 shows the estimated WTP for each product, by origin and treatment, for all consumers (including those who stated that they did not eat seaweed or shellfish). Finally, panel I of tables 3 through 6 shows the estimated WTP for each product, by origin and treatment, for nonconsumers of seaweed or shellfish. Overall, about $34 \%$ of respondents stated that they ate seaweed, while $79 \%$ stated that they ate shellfish. 


\subsection{Summary of results}

Treatment 2 - the economic information treatment — increased WTP for seaweed products from Connecticut, Maine, and Korea, while Treatment 1 -information about health, safety, and the environment - had a more limited positive effect on seaweed from Connecticut and Maine and decreased WTP for seaweed from China. T1 also had a negative effect on demand for shellfish products from regions other than Connecticut. Women tended to respond more strongly than men to the information treatments; college graduates tended to respond more strongly to $\mathrm{T} 2$ while non-graduates tended to respond more strongly to $\mathrm{T} 1$. We also find that $\mathrm{T} 2$ increased WTP for Connecticut shellfish products when considering all respondents—not just those who stated that they ate shellfish. Lastly, we find that T2 increased WTP for Connecticut seaweed noodles and oysters, among non-consumers of seaweed and shellfish. Overall, the effects of the information treatments on WTP were stronger for consumers than for nonconsumers.

\subsection{Seaweed noodles}

In Table 3, panel A, we present WTP estimates for seaweed noodles for all respondents who stated that they ate seaweed. The estimated WTP for respondents in the control group is about $\$ 15 / 1 b$. for Connecticut-grown seaweed noodles, $\$ 14 /$ lb. for Maine-grown seaweed noodles, $\$ 9 / \mathrm{lb}$. for seaweed noodles from Korea, and $\$ 8 / \mathrm{lb}$. for seaweed noodles from China. The difference in WTP for Connecticut-grown and Maine-grown noodles is not statistically significant. T2 increased WTP for Korea-grown seaweed noodles by about $\$ 2 / 1 b$. 
Results by demographic characteristics.-T2 increased women's WTP for Korea-grown seaweed noodles by about $\$ 3 / 1$ b. (table 3, panel B). T2 also increased below-median-income respondents’ WTP for Korea-grown seaweed noodles, by about \$3/lb. (table 3, panel G). ${ }^{10}$

Results for all respondents. - Among all respondents (including those who eat and those who do not eat seaweed), T1 increased WTP for Connecticut-grown seaweed noodles by about $\$ 1 / 1 b$, and T2 increased WTP for Connecticut-grown seaweed noodles by about $\$ 2 / 1 b$. (table 3 , panel H). T2 also increased WTP for Maine-grown seaweed noodles by about \$1/lb.

Results for seaweed non-consumers.-Among respondents who do not eat seaweed, T2 increased WTP for Connecticut-grown seaweed noodles by about \$4/lb. (table 3, panel I). This result suggests that providing information about the local economic benefits of local food may inspire consumers to try products they had not tried before.

\subsection{Farmed raw, fresh seaweed}

In Table 4, panel A, we present WTP estimates for farmed raw, fresh seaweed for all respondents who stated that they ate seaweed. The estimated WTP for respondents in the control group is about $\$ 8 / \mathrm{lb}$. for Connecticut-grown fresh seaweed, $\$ 7 / \mathrm{lb}$. for Maine-grown fresh seaweed, \$3/lb. for China-grown fresh seaweed, and \$2/lb. for Korea-grown fresh seaweed. T2 increased WTP for Connecticut-grown fresh seaweed by about \$2/lb., for Maine-grown fresh seaweed by about $\$ 2 / 1 b$., and for China-grown fresh seaweed by about $\$ 3 / 1 b$.

\footnotetext{
10 We hypothesized that the results for Korea-grown seaweed noodles may have been driven by random assignment of ethnic Korean respondents into T2, but regression results for the subset of Asian respondents do not support this hypothesis; for this subset, the effect of T2 on demand for Korea-grown seaweed noodles is insignificant. These results are not shown in the tables in the paper because the sample size for Asian and Black respondents is too small to yield meaningful WTP estimates for some of the treatment cells and some products.
} 
Results by demographic characteristics.-Both information treatments increased women's WTP for Connecticut-grown fresh seaweed by about \$2/lb. (table 4, panel B). T2 also increased women's WTP for fresh seaweed grown in Maine and Korea (by about \$4/lb. and \$3/lb., respectively). T2 increased college graduates' WTP for fresh seaweed grown in Connecticut, Maine, and Korea (by about $\$ 2 / 1$ b., $\$ 3 / 1 b$. , and $\$ 4 / 1 b$., respectively) (panel D). T2 also increased above-median-income respondents' WTP for fresh seaweed grown in Connecticut and Maine (by about \$2/lb. and \$3/lb., respectively) (panel F). T1 decreased above-medianincome respondents' WTP for China-grown fresh seaweed by about $\$ 6 / \mathrm{lb}$. T1 also increased below-median-income respondents' WTP for fresh seaweed grown in Connecticut and Maine (by about $\$ 4 / \mathrm{lb}$. and $\$ 3 / \mathrm{lb}$., respectively) (panel G). Finally, T2 increased below-median-income respondents' WTP for Korea-grown fresh seaweed by about $\$ 4 / 1 b$.

Results for all respondents.-Among all respondents (including those who eat and those who do not eat seaweed), T2 increased WTP for Connecticut-grown fresh seaweed by about \$1/lb. (table 4, panel H).

\subsection{Farm-raised clams, quahog littlenecks, raw, on the half shell}

In Table 5, panel A, we present WTP estimates for farm-raised clams, quahog littlenecks, raw, on the half shell for all respondents who stated that they ate shellfish. The estimated WTP for respondents in the control group is about $\$ 9 /$ dozen for Connecticut- or Rhode Island-raised clams, and \$4/dozen for Florida- or Virginia-raised clams. T1 decreased WTP for Virginia-raised clams by about $\$ 2 /$ dozen. 
Results by demographic characteristics.-T1 decreased women's WTP for Virginiaraised clams by about $\$ 3 /$ dozen (table 5 , panel B). T1 decreased non-college-graduates' WTP for clams raised in Florida by about $\$ 3 /$ dozen (panel E). T1 decreased below-median-income respondents’ WTP for clams from Rhode Island, Florida, and Virginia (by about \$1/dozen, \$3/dozen, and \$4/dozen, respectively) (panel G).

Results for all respondents. - Among all respondents (including those who eat and those who do not eat shellfish), T2 increased WTP for Connecticut-raised clams by about $\$ 0.90 /$ dozen (table 5, panel H).

\subsection{Farm-raised oysters, raw, on the half shell}

In Table 6, panel A, we present WTP estimates for farm-raised oysters, raw, on the half shell for all respondents who stated that they ate shellfish. The estimated WTP for respondents in the control group is about $\$ 14 /$ dozen for Connecticut-raised oysters, $\$ 13 /$ dozen for Maine-raised oysters, \$10/dozen for Washington-raised oysters, and \$9/dozen for Louisiana-raised oysters. T1 decreased WTP for Louisiana-raised oysters by about \$2/dozen.

Results by demographic characteristics.-T1 decreased non-college-graduates' WTP for Washington-raised oysters by about \$2/dozen (table 6, panel E).

Results for all respondents. - Among all respondents (including those who eat and those who do not eat shellfish), T2 increased WTP for Connecticut-raised oysters by about \$0.60/dozen (table 6, panel H).

Results for shellfish non-consumers.-Among respondents who do not eat shellfish, T2 increased WTP for Connecticut-raised oysters by about \$3/dozen (table 6, panel I). Along with 
the result for seaweed noodles (table 3, panel I), this suggests that providing information about the local economic benefits of local food may inspire consumers to try new products.

\section{Conclusion}

Our findings suggest that Connecticut respondents were more likely to purchase seaweed or shellfish from their state, rather than other states or countries. Providing either type of information increases the WTP for Connecticut-grown products for all seafood types examined. Our findings are consistent with Brayden et al. (2018), who found that production location was particularly important to their respondents. More broadly, respondents in our study were willing to pay more for seafood from the New England region compared to seafood from other states or overseas.

We found that T2 (information about the economic contribution of the aquaculture industry) had a stronger and more consistent effect on increasing WTP for Connecticut products than T1 (information about health, safety, and the environment). Instead, T1 tended to decrease WTP for products from locations other than Connecticut (and particularly locations outside New England). We suggest that respondents associated T2 more strongly with a reason to consume locally produced products than $\mathrm{T} 1$ and that respondents might have a negative opinion about the environmental conditions in places such as Virginia, Florida, Louisiana, Washington, and China.

A few limitations are worth mentioning. First, the information treatments have a limited effect on demand, for limited groups of potential consumers. We should note that this is an online survey with nothing at stake, and that we expect market effects of such treatments would be more muted. Second, many other attributes (such as freshness and wild caught or farm raised) 
may affect consumers' seafood choices. Future research on this topic could consider including more attributes in the choice experiment, although as we have discussed, some participants in our pilot expressed frustration and perplexity when facing choices over multiple product-attribute dimensions. Thirdly, our study had narrow geographical and ethnic coverage. Only Connecticut residents were eligible to participate in our study. As described above, the respondents mainly described themselves as white. We had hoped that our study might help to shed light on nutritional inequities by race and ethnicity but many of the treatment and control cells have too few Asian and Black respondents to allow for useful estimation and statistical inference of WTP for these cells and demographic groups. 


\section{Acknowledgments}

The authors appreciate advice from Nancy Balcom, Robert Johnston, Sarah Kolesar, Dawn

Kotowicz, Nathan Fiala, Pengfei Liu, Brandon McFadden, Mark Needham, Stephen Swallow, Charles Towe, Jonathan van Senten, and Kirsten Winters.

\section{Financial Disclosure}

This project received support from NOAA Sea Grant under the Aquaculture Extension and Technology Transfer 2015 (NOAA-OAR-SG-2015-2004399); NOAA National Sea Grant under grant number NA14OAR4170086; and USDA Multistate Research Project W3004.

\section{Conflicts of Interest}

The authors declare no conflicts of interest.

\section{Data Availability Statement}

Upon acceptance of the article, we will make all data and estimation code available online for replication. 


\section{References}

Alfnes, F., Guttormsen, A. G., Steine, G., \& Kolstad, K. (2006). Consumers' willingness to pay for the color of salmon: a choice experiment with real economic incentives. American Journal of Agricultural Economics, 88(4), 1050-1061.

Bartneck, C., Duenser, A., Moltchanova, E., \& Zawieska, K. (2015). Comparing the similarity of responses received from studies in Amazon's Mechanical Turk to studies conducted online and with direct recruitment. PloS one, 10(4), e0121595.

Bi, X., House, L., \& Gao, Z. (2016). Impacts of nutrition information on choices of fresh seafood among parents. Marine Resource Economics, 31(3), 355-372.

Boehm, R., \& Bovay, J. (2018). Consumer Purchases of Connecticut-Grown Food and Farm Products Update 2015 (Outreach Report \#52): Zwick Center for Food and Resource Policy.

Bouchard, D., Camire, M.E., Davis, C., Shaler, G., Dumont, R., Bernier, R. \& Labbe, R. (2021). Attitudes toward aquaculture and seafood purchasing preferences: Evidence from a consumer survey of Atlantic States, Aquaculture Economics \& Management, DOI: $10.1080 / 13657305.2020 .1869859$

Brayden, W. C., Noblet, C. L., Evans, K. S., \& Rickard, L. (2018). Consumer preferences for seafood attributes of wild-harvested and farm-raised products. Aquaculture Economics \& Management, 1-21.

Cameron, A. C., \& Trivedi, P. K. (2010). Microeconometrics using Stata (Vol. 2): Stata press College Station, TX. 
Casler, K., Bickel, L., \& Hackett, E. (2013). Separate but equal? A comparison of participants and data gathered via Amazon's MTurk, social media, and face-to-face behavioral testing. Computers in Human Behavior, 29(6), 2156-2160.

Feldmann, C., \& Hamm, U. (2015). Consumers' perceptions and preferences for local food: A review. Food Quality and Preference, 40, 152-164.

Fonner, R., \& Sylvia, G. 2015. Willingness to pay for multiple seafood labels in a niche market. Marine Resource Economics 30(1):51-70.

Getchis, T.L., De Guise, S. \& D.H. Carey. 2020. Impacts of COVID-19 on Connecticut Aquaculture Industry: A Preliminary Report. Connecticut Sea Grant. CTSG-20-12. 3pp.

Green, P. E., \& Srinivasan, V. (1990). Conjoint analysis in marketing: new developments with implications for research and practice. The Journal of Marketing, 3-19.

Holland, D., \& Wessells, C. R. (1998). Predicting consumer preferences for fresh salmon: the influence of safety inspection and production method attributes. Agricultural and Resource Economics Review, 27(1), 1-14.

Kecinski, M., Messer, K. D., Knapp, L., \& Shirazi, Y. (2017). Consumer Preferences for Oyster Attributes: Field Experiments on Brand, Locality, and Growing Method. Agricultural and Resource Economics Review, 46(2), 315-337.

Krinsky, I., \& Robb, A. L. (1986). On approximating the statistical properties of elasticities. The Review of Economics and Statistics, 715-719.

Kuchler, F., Krissoff, B., \& Harvey, D. (2010). Do consumers respond to country-of-origin labelling? Journal of Consumer Policy, 33(4), 323-337. 
Li, T., Kecinski, M., \& Messer, K. D. (2017). Heterogeneous Preferences for Oysters: Evidence from Field Experiments. Agricultural and Resource Economics Review, 46(2), 296-314.

Loose, S. M., Peschel, A., \& Grebitus, C. (2013). Quantifying effects of convenience and product packaging on consumer preferences and market share of seafood products: The case of oysters. Food Quality and Preference, 28(2), 492-504.

Manalo, A. B., \& Gempesaw, C. M. (1997). Preferences for oyster attributes by consumers in the US Northeast. Journal of Food Distribution Research, 28(2).

McFadden, D. (1973). “Conditional logit analysis of qualitative choice behavior.” In Frontiers in Econometrics, P. Zarembka (ed.) New York: Academic Press. Chapter 4, pp. 105-142.

Orme, B. (2010). Getting Started with Conjoint Analysis: Strategies for Product Design and Pricing Research. Second Edition, Madison, Wis.

Ortega, D. L., Wang, H. H., \& Olynk Widmar, N. J. (2014). Aquaculture imports from Asia: an analysis of US consumer demand for select food quality attributes. Agricultural Economics, 45(5), 625-634.

Printezis, I., Grebitus, C., \& Hirsch, S. (2019). The price is right!? A meta-regression analysis on willingness to pay for local food. PloS one, 14(5), e0215847.

Quagrainie, K., Hart, S., \& Brown, P. (2008). Consumer acceptance of locally grown food: the case of Indiana aquaculture products. Aquaculture Economics \& Management, 12(1), 5470.

Robidoux, J., and Chadsey, M. (2020). State of the States: Status of U.S. Seaweed Aquaculture. Maine Sea Grant and Washington Sea Grant. https://seaweedhub.org/wp- 
content/uploads/2020/07/State-of-the-States-Rev_APC_7-16-20.pptx.pdf.

Roheim, C. A., Sudhakaran, P. O., \& Durham, C. A. (2012). Certification of shrimp and salmon for best aquaculture practices: Assessing consumer preferences in Rhode Island. Aquaculture Economics \& Management, 16(3), 266-286.

Ropicki, A. J., Larkin, S. L., \& Adams, C. M. (2010). Seafood substitution and mislabeling: WTP for a locally caught grouper labeling program in Florida. Marine Resource Economics, 25(1), 77-93.

Shamshak, G. L., Tookes, J. S., \& Yandle, T. (2020). Evaluating the Economic Viability of Inland Seafood Markets in Georgia: A Two-Pronged Approach. Marine Resource Economics, $35(1), 21-42$.

Thapa, G., Dey, M. M., \& Engle, C. (2015). Consumer preferences for live seafood in the northeastern region of USA: results from Asian ethnic fish market survey. Aquaculture Economics \& Management, 19(2), 210-225.

Thurstone, L. L. (1927). A law of comparative judgment. Psychological review, 34(4), 273.

van Senten, J, Engle, CR, Smith, MA. Effects of COVID-19 on U.S. Aquaculture Farms. (2021). Applied Economic Perspectives and Policy, 43(1), 355-367.

https://doi.org/10.1002/aepp.13140 
Figure 1. Example of a choice set used in the choice experiment.

\section{Please read the following before continuing:}

This last set of questions will ask you to choose between a variety of seafood products. Note that similar questions are asked four times. We do this to narrow down to the level of detail we need to draw conclusions. We ask that you consider these next product choice questions as if they were real-life purchase decisions you were making in your local food market.

Which of the following farmed seaweed noodle products would you choose? (Each is $1 \mathrm{lb}$.)

Product of Connecticut, USA, $\$ 13$

Product of Korea, $\$ 11$

Product of China, $\$ 12$

Product of Maine, USA, $\$ 10$

None of these 
Figure 2. Information treatments.

Panel A: Information treatment 1.

\section{Please keep the following in mind before continuing:}

Connecticut seafood is a nutritious food containing a good source of protein, heart-healthy fats and vitamins, and minerals.

Connecticut regulations exist to ensure safe seafood production, harvesting, processing, and transport.

Connecticut aquaculture products are grown in Long Island Sound without the input of feed, fertilizers or antibiotics, and generate environmental benefits.

Panel B: Information treatment 2.

\section{Please keep the following in mind before continuing:}

Connecticut aquaculture production is valued at greater than $\$ 30,000,000$ per year and provides over 300 jobs. 
Table 1. Products, attributes, and prices used in the choice experiment.

\begin{tabular}{lll} 
Products & Production Locations & Prices \\
\hline Seaweed noodles, $1 \mathrm{lb}$., farmed & Connecticut, Maine, China, Korea & $\$ 10, \$ 11, \$ 12, \$ 13$ \\
Raw/fresh seaweed, 1 lb., & Connecticut, Maine, China, Korea & $\$ 5, \$ 6, \$ 7, \$ 8$ \\
farmed & & \\
Clams: Raw, on the half shell, 1 & Connecticut, Florida, Virginia, & $\$ 6, \$ 7, \$ 8, \$ 9$ \\
dozen, farmed & $\begin{array}{l}\text { Rhode Island } \\
\text { Oysters: Raw, on the half shell, }\end{array}$ & Connecticut, Louisiana, \\
1 dozen, farmed & Washington, Maine & $\$ 12, \$ 13, \$ 14, \$ 15$ \\
\hline
\end{tabular}


Table 2. Demographics of survey participants

\begin{tabular}{|c|c|c|c|c|c|}
\hline Variables & Description & Pooled sample & Treatment 1 & Treatment 2 & Control \\
\hline \multicolumn{2}{|c|}{ Number of respondents } & 1,756 & 583 & 588 & 585 \\
\hline \multirow[t]{2}{*}{ Gender } & Female & 946 & 309 & 305 & 332 \\
\hline & & $(53.9 \%)$ & & & \\
\hline \multirow[t]{16}{*}{ Race } & Hispanic or Latino & 88 & 29 & 31 & 28 \\
\hline & & $(5.01 \%)$ & & & \\
\hline & Black or African & 73 & 29 & 23 & 21 \\
\hline & American & $(4.16 \%)$ & & & \\
\hline & White (Not & 1464 & 494 & 490 & 480 \\
\hline & Hispanic or Latino) & $(83.37 \%)$ & & & \\
\hline & American Indian or & 7 & 4 & 3 & 0 \\
\hline & Alaska Native & $(0.40 \%)$ & & & \\
\hline & Asian & 73 & 16 & 23 & 34 \\
\hline & & $(4.16 \%)$ & & & \\
\hline & Native Hawaiian or & 1 & 1 & 0 & 0 \\
\hline & Pacific Island & $(0.06 \%)$ & & & \\
\hline & Some other race & 14 & 4 & 3 & 7 \\
\hline & $\begin{array}{l}\text { not listed in the } \\
\text { survey }\end{array}$ & $(0.80 \%)$ & & & \\
\hline & Two or more races & 36 & 6 & 15 & 15 \\
\hline & & $(2.95 \%)$ & & & \\
\hline \multirow[t]{8}{*}{ Age } & $18-29$ & 304 & 115 & 99 & 90 \\
\hline & & $(17.31 \%)$ & & & \\
\hline & $30-39$ & 271 & 87 & 88 & 96 \\
\hline & & $(15.43 \%)$ & & & \\
\hline & $40-49$ & 290 & 99 & 95 & 96 \\
\hline & & $(16.51 \%)$ & & & \\
\hline & $50-59$ & 349 & 105 & 120 & 124 \\
\hline & & $(19.87 \%)$ & & & \\
\hline & $60-69$ & 338 & 98 & 119 & 121 \\
\hline & & $(19.25 \%)$ & & & \\
\hline & 70 and above & 204 & 79 & 67 & 58 \\
\hline & & $(11.62 \%)$ & & & \\
\hline Education & Some high school & 19 & 8 & 4 & 7 \\
\hline & & $(1.08 \%)$ & & & \\
\hline & High school & 228 & 68 & 78 & 82 \\
\hline & graduate & $(12.98 \%)$ & & & \\
\hline & Some college & 361 & 128 & 117 & 116 \\
\hline & & $(20.56 \%)$ & & & \\
\hline
\end{tabular}




\begin{tabular}{|c|c|c|c|c|c|}
\hline & Trade/Technical/ & 93 & 31 & 27 & 35 \\
\hline & Vocational training & $(5.30 \%)$ & & & \\
\hline & College graduate & 561 & 192 & 198 & 171 \\
\hline & & $(31.95 \%)$ & & & \\
\hline & Post graduate work & 79 & 31 & 17 & 31 \\
\hline & & $(4.50 \%)$ & & & \\
\hline & Post graduate & 415 & 125 & 147 & 143 \\
\hline & degree & $(23.63 \%)$ & & & \\
\hline Income & Less than $\$ 10,000$ & 77 & 22 & 33 & 22 \\
\hline & & $(4.38 \%)$ & & & \\
\hline & $\$ 10,000-\$ 14,999$ & 60 & 22 & 21 & 17 \\
\hline & & $(3.42 \%)$ & & & \\
\hline & $\$ 15,000-\$ 24,999$ & 115 & 39 & 37 & 39 \\
\hline & & $(6.55 \%)$ & & & \\
\hline & $\$ 25,000-\$ 34,999$ & 131 & 44 & 45 & 42 \\
\hline & & $(7.46 \%)$ & & & \\
\hline & $\$ 35,000-\$ 49,999$ & 204 & 69 & 65 & 70 \\
\hline & & $(11.62 \%)$ & & & \\
\hline & $\$ 50,000-\$ 74,999$ & 282 & 88 & 85 & 109 \\
\hline & & $(16.06 \%)$ & & & \\
\hline & $\$ 75,000-\$ 99,999$ & 230 & 84 & 83 & 163 \\
\hline & & $(13.10 \%)$ & & & \\
\hline & $\$ 100,000-$ & 309 & 104 & 99 & 106 \\
\hline & $\$ 149,999$ & $(17.60 \%)$ & & & \\
\hline & $\$ 150,000-$ & 180 & 55 & 63 & 62 \\
\hline & $\$ 199,999$ & $(10.25 \%)$ & & & \\
\hline & $\$ 200,000$ or more & 168 & 56 & 57 & 55 \\
\hline & & $(9.57 \%)$ & & & \\
\hline
\end{tabular}

Note: We conducted Wilcoxon-Mann-Whitney tests between the control group and each of the treatment groups to test if they have the same distribution using Stata's rank sum test. All test statistics, except race, were not significant at 5\%, indicating that we cannot reject the null hypotheses. Note that treatment 1 and treatment 2 are two separate treatments and that individuals in the treatment groups saw only one of the two statements randomly. We present the share of each classification in parentheses for the pooled sample. 
Table 3. Estimated WTP for seaweed noodles (\$/lb.)

\begin{tabular}{lcccc}
\hline & Connecticut & Maine & Korea & China \\
\hline Panel A: Respondents who eat seaweed & & & \\
Treatment 1 & 15.28 & 13.65 & 10.05 & 8.21 \\
& $(14.37,16.61)$ & $(12.89,14.63)$ & $(9.00,10.98)$ & $(6.83,9.31)$ \\
Treatment 2 & 15.08 & 14.36 & 11.00 & 9.82 \\
& $(14.18,16.31)$ & $(13.54,15.44)$ & $(10.11,11.88)$ & $(8.81,10.74)$ \\
Control & 14.83 & 13.81 & 8.91 & 8.27 \\
& $(13.88,16.26)$ & $(12.99,14.94)$ & $(7.46,10.03)$ & $(6.79,9.39)$ \\
\hline \multirow{2}{*}{ Panel B: Female respondents who eat seaweed } & & & \\
Treatment 1 & 15.61 & 13.66 & 10.69 & 7.93 \\
Treatment 2 & $(14.49,17.18)$ & $(12.70,14.88)$ & $(9.42,11.86)$ & $(6.08,9.48)$ \\
& 15.80 & 15.05 & 12.01 & 10.62 \\
Control & $(14.61,17.41)$ & $(13.92,16.54)$ & $(10.82,13.24)$ & $(9.31,11.94)$ \\
& 14.59 & 13.67 & 9.05 & 8.62 \\
\hline
\end{tabular}

Panel C: Male respondents who eat seaweed

\begin{tabular}{lcccc} 
Treatment 1 & 15.04 & 13.66 & 8.70 & 8.41 \\
Treatment 2 & $(13.93,16.57)$ & $(12.61,14.96)$ & $(6.79,10.35)$ & $(6.52,10.01)$ \\
& 14.43 & 13.72 & 9.62 & 8.76 \\
Control & $(13.41,15.76)$ & $(12.75,14.93)$ & $(8.08,10.99)$ & $(7.12,10.20)$ \\
& 15.23 & 14.05 & 8.61 & 7.47 \\
& $(13.91,17.08)$ & $(12.81,15.63)$ & $(6.36,10.52)$ & $(4.99,9.50)$ \\
\hline
\end{tabular}

Panel D: College graduates who eat seaweed

\begin{tabular}{|c|c|c|c|c|}
\hline Treatment 1 & $\begin{array}{c}15.90 \\
(14.78,17.47)\end{array}$ & $\begin{array}{c}14.02 \\
(13.06,15.26)\end{array}$ & $\begin{array}{c}10.94 \\
(9.76,12.07)\end{array}$ & $\begin{array}{c}8.47 \\
(6.81,9.90)\end{array}$ \\
\hline Treatment 2 & $\begin{array}{c}15.10 \\
(14.13,16.40)\end{array}$ & $\begin{array}{c}14.29 \\
(13.40,15.45)\end{array}$ & $\begin{array}{c}10.72 \\
(9.59,11.76)\end{array}$ & $\begin{array}{c}8.02 \\
(6.37,9.42)\end{array}$ \\
\hline Control & $\begin{array}{c}14.72 \\
(13.70,16.18)\end{array}$ & $\begin{array}{c}13.72 \\
(12.81,14.94)\end{array}$ & $\begin{array}{c}8.65 \\
(6.90,9.99)\end{array}$ & $\begin{array}{c}6.10 \\
(3.72,7.90)\end{array}$ \\
\hline \multicolumn{5}{|c|}{ Panel E: Respondents with no college degree who eat seaweed } \\
\hline Treatment 1 & $\begin{array}{c}14.28 \\
(13.26,15.61)\end{array}$ & $\begin{array}{c}13.13 \\
(12.14,14.30)\end{array}$ & $\begin{array}{c}8.50 \\
(6.60,10.14)\end{array}$ & $\begin{array}{c}7.92 \\
(5.98,9.55)\end{array}$ \\
\hline Treatment 2 & $\begin{array}{c}14.85 \\
(13.59,16.46)\end{array}$ & $\begin{array}{c}14.38 \\
(13.14,15.87)\end{array}$ & $\begin{array}{c}11.58 \\
(10.08,13.07)\end{array}$ & $\begin{array}{c}11.91 \\
(10.54,13.40)\end{array}$ \\
\hline Control & $\begin{array}{c}14.99 \\
(13.66,16.84)\end{array}$ & $\begin{array}{c}13.96 \\
(12.67,15.59)\end{array}$ & $\begin{array}{c}9.46 \\
(7.42,11.24)\end{array}$ & $\begin{array}{c}10.71 \\
(9.12,12.31)\end{array}$ \\
\hline
\end{tabular}




\begin{tabular}{|c|c|c|c|c|}
\hline Noodles & Connecticut & Maine & Korea & China \\
\hline \multicolumn{5}{|c|}{ Panel F: Respondents with household income at least $\$ 75,000$ who eat seaweed } \\
\hline Treatment 1 & $\begin{array}{c}14.74 \\
(13.81,16.02)\end{array}$ & $\begin{array}{c}12.81 \\
(11.96,13.81)\end{array}$ & $\begin{array}{c}9.94 \\
(8.67,11.04)\end{array}$ & $\begin{array}{c}5.33 \\
(2.62,7.47)\end{array}$ \\
\hline Treatment 2 & $\begin{array}{c}14.94 \\
(13.95,16.27)\end{array}$ & $\begin{array}{c}13.98 \\
(13.05,15.14)\end{array}$ & $\begin{array}{c}9.60 \\
(8.14,10.88)\end{array}$ & $\begin{array}{c}8.21 \\
(6.52,9.66)\end{array}$ \\
\hline Control & $\begin{array}{c}14.93 \\
(13.81,16.51)\end{array}$ & $\begin{array}{c}13.83 \\
(12.81,15.17)\end{array}$ & $\begin{array}{c}8.76 \\
(6.88,10.24)\end{array}$ & $\begin{array}{c}7.29 \\
(5.15,8.99)\end{array}$ \\
\hline
\end{tabular}

Panel G: Respondents with household income less than $\$ 75,000$ who eat seaweed

\begin{tabular}{lcccc} 
Treatment 1 & 16.15 & 14.88 & 10.28 & 10.55 \\
& $(14.84,17.97)$ & $(13.68,16.42)$ & $(8.59,11.84)$ & $(9.07,12.04)$ \\
Treatment 2 & 15.22 & 14.83 & 12.33 & 11.28 \\
& $(14.05,16.77)$ & $(13.69,16.27)$ & $(11.09,13.61)$ & $(10.01,12.64)$ \\
Control & 14.69 & 13.77 & 9.09 & 9.12 \\
& $(13.54,16.31)$ & $(12.70,15.15)$ & $(7.26,10.61)$ & $(7.45,10.56)$ \\
\hline
\end{tabular}

Panel H: All respondents

\begin{tabular}{lcccc} 
Treatment 1 & 10.18 & 8.59 & 2.68 & 1.27 \\
& $(9.81,10.50)$ & $(7.91,9.10)$ & $(0.56,4.20)$ & $(-1.09,2.96)$ \\
Treatment 2 & 10.68 & 9.12 & 4.33 & 3.93 \\
& $(10.41,10.95)$ & $(8.62,9.52)$ & $(2.85,5.45)$ & $(2.47,5.04)$ \\
Control & 8.95 & 7.87 & 1.15 & 0.60 \\
& $(8.28,9.42)$ & $(6.88,8.55)$ & $(-1.76,3.11)$ & $(-2.36,2.55)$ \\
\hline
\end{tabular}

Panel I: Respondents who do not eat seaweed

\begin{tabular}{lcccc} 
Treatment 1 & 7.50 & 6.09 & -4.65 & -3.92 \\
& $(5.93,8.39)$ & $(3.89,7.34)$ & $(-11.89,-0.50)$ & $(-10.68,-0.18)$ \\
Treatment 2 & 9.28 & 6.84 & -2.62 & 0.60 \\
& $(8.65,9.72)$ & $(5.48,7.73)$ & $(-7.52,0.70)$ & $(-2.82,2.79)$ \\
Control & 5.57 & 4.51 & -5.42 & -5.88 \\
& $(2.46,7.06)$ & $(0.72,6.35)$ & $(-15.31,-0.62)$ & $(-15.87,-1.14)$ \\
\hline
\end{tabular}

Notes: For panel A, the WTP estimates are calculated from the results from Appendix Table A2. For all other panels, the WTP estimates are calculated from equivalent results for subsamples of the entire set of responses. The top line of each cell is estimated mean WTP, and 95\% confidence intervals (calculated using the Krinsky-Robb procedure) are shown in parentheses. 
Table 4. Estimated WTP for farmed raw, fresh seaweed (\$/lb.)

\begin{tabular}{|c|c|c|c|c|}
\hline & Connecticut & Maine & Korea & China \\
\hline \multicolumn{5}{|c|}{ Panel A: Respondents who eat seaweed } \\
\hline Treatment 1 & $\begin{array}{c}9.48 \\
(8.69,10.65)\end{array}$ & $\begin{array}{c}7.55 \\
(6.89,8.36)\end{array}$ & $\begin{array}{c}1.59 \\
(-0.33,2.97)\end{array}$ & $\begin{array}{c}1.02 \\
(-1.12,2.53)\end{array}$ \\
\hline Treatment 2 & $\begin{array}{c}9.93 \\
(9.11,11.02)\end{array}$ & $\begin{array}{c}9.16 \\
(8.41,10.14)\end{array}$ & $\begin{array}{c}3.83 \\
(2.63,4.84)\end{array}$ & $\begin{array}{c}5.35 \\
(4.48,6.19)\end{array}$ \\
\hline Control & $\begin{array}{c}8.22 \\
(7.71,8.88) \\
\end{array}$ & $\begin{array}{c}6.83 \\
(6.34,7.37) \\
\end{array}$ & $\begin{array}{c}2.96 \\
(1.82,3.85) \\
\end{array}$ & $\begin{array}{c}1.89 \\
(0.46,3.01) \\
\end{array}$ \\
\hline \multicolumn{5}{|c|}{ Panel B: Female respondents who eat seaweed } \\
\hline Treatment 1 & $\begin{array}{c}9.77 \\
(8.80,11.16)\end{array}$ & $\begin{array}{c}7.75 \\
(6.88,8.83)\end{array}$ & $\begin{array}{c}0.36 \\
(-2.54,2.49)\end{array}$ & $\begin{array}{c}1.87 \\
(-0.30,3.54)\end{array}$ \\
\hline Treatment 2 & $\begin{array}{c}9.91 \\
(8.98,11.13)\end{array}$ & $\begin{array}{c}8.79 \\
(7.92,9.86)\end{array}$ & $\begin{array}{c}5.72 \\
(4.65,6.75)\end{array}$ & $\begin{array}{c}3.30 \\
(1.68,4.72)\end{array}$ \\
\hline Control & $\begin{array}{c}7.58 \\
(7.06,8.22)\end{array}$ & $\begin{array}{c}6.27 \\
(5.70,6.86)\end{array}$ & $\begin{array}{c}1.25 \\
(-0.50,2.62)\end{array}$ & $\begin{array}{c}2.98 \\
(1.77,3.96)\end{array}$ \\
\hline
\end{tabular}

Panel C: Male respondents who eat seaweed

\begin{tabular}{|c|c|c|c|c|}
\hline Treatment 1 & $\begin{array}{c}9.24 \\
(8.25,10.61)\end{array}$ & $\begin{array}{c}7.28 \\
(6.31,8.39)\end{array}$ & $\begin{array}{c}1.13 \\
(-1.47,3.14)\end{array}$ & $\begin{array}{c}0.90 \\
(-1.86,2.99)\end{array}$ \\
\hline Treatment 2 & $\begin{array}{c}10.33 \\
(9.19,11.80)\end{array}$ & $\begin{array}{c}9.97 \\
(8.86,11.37)\end{array}$ & $\begin{array}{c}5.01 \\
(3.49,6.45)\end{array}$ & $\begin{array}{c}4.79 \\
(3.18,6.31)\end{array}$ \\
\hline Control & $\begin{array}{c}9.63 \\
(8.68,10.84) \\
\end{array}$ & $\begin{array}{c}8.13 \\
(7.21,9.22)\end{array}$ & $\begin{array}{c}3.44 \\
(1.64,5.05)\end{array}$ & $\begin{array}{c}3.05 \\
(1.15,4.73)\end{array}$ \\
\hline \multicolumn{5}{|c|}{ Panel D: College graduates who eat seaweed } \\
\hline Treatment 1 & $\begin{array}{c}9.07 \\
(8.26,10.20)\end{array}$ & $\begin{array}{c}7.22 \\
(6.47,8.08)\end{array}$ & $\begin{array}{c}-0.60 \\
(-3.62,1.61)\end{array}$ & $\begin{array}{c}0.16 \\
(-2.45,2.10)\end{array}$ \\
\hline Treatment 2 & $\begin{array}{c}10.18 \\
(9.26,11.39)\end{array}$ & $\begin{array}{c}9.21 \\
(8.35,10.29)\end{array}$ & $\begin{array}{c}5.15 \\
(4.02,6.18)\end{array}$ & $\begin{array}{c}2.02 \\
(0.02,3.70)\end{array}$ \\
\hline Control & $\begin{array}{c}8.07 \\
(7.52,8.76)\end{array}$ & $\begin{array}{c}6.52 \\
(5.95,7.12)\end{array}$ & $\begin{array}{c}1.32 \\
(-0.46,2.72)\end{array}$ & $\begin{array}{c}0.04 \\
(-2.21,1.84)\end{array}$ \\
\hline \multicolumn{5}{|c|}{ Panel E: Respondents with no college degree who eat seaweed } \\
\hline Treatment 1 & $\begin{array}{c}10.34 \\
(9.11,12.03)\end{array}$ & $\begin{array}{c}8.28 \\
(7.14,9.69)\end{array}$ & $\begin{array}{c}3.24 \\
(1.11,5.05)\end{array}$ & $\begin{array}{c}3.72 \\
(1.69,5.45)\end{array}$ \\
\hline Treatment 2 & $\begin{array}{c}9.24 \\
(8.16,10.57)\end{array}$ & $\begin{array}{c}8.97 \\
(7.90,10.26)\end{array}$ & $\begin{array}{c}5.69 \\
(4.34,7.01)\end{array}$ & $\begin{array}{c}5.61 \\
(4.20,6.99)\end{array}$ \\
\hline Control & $\begin{array}{c}8.54 \\
(7.69,9.57)\end{array}$ & $\begin{array}{c}7.51 \\
(6.66,8.49)\end{array}$ & $\begin{array}{c}3.04 \\
(1.32,4.56)\end{array}$ & $\begin{array}{c}5.53 \\
(4.43,6.60)\end{array}$ \\
\hline
\end{tabular}




\begin{tabular}{|c|c|c|c|c|}
\hline Raw seaweed & Connecticut & Maine & Korea & China \\
\hline \multicolumn{5}{|c|}{ Panel F: Respondents with household income at least $\$ 75,000$ who eat seaweed } \\
\hline Treatment 1 & $\begin{array}{c}8.46 \\
(7.71,9.47)\end{array}$ & $\begin{array}{c}6.01 \\
(5.17,6.83)\end{array}$ & $\begin{array}{c}-1.01 \\
(-4.18,1.26)\end{array}$ & $\begin{array}{c}-4.21 \\
(-9.13,-0.51)\end{array}$ \\
\hline Treatment 2 & $\begin{array}{c}10.70 \\
(9.62,12.12)\end{array}$ & $\begin{array}{c}9.86 \\
(8.83,11.17)\end{array}$ & $\begin{array}{c}4.55 \\
(3.03,5.91)\end{array}$ & $\begin{array}{c}1.31 \\
(-1.39,3.61)\end{array}$ \\
\hline Control & $\begin{array}{c}8.39 \\
(7.75,9.19)\end{array}$ & $\begin{array}{c}6.81 \\
(6.16,7.52)\end{array}$ & $\begin{array}{c}1.89 \\
(0.13,3.31)\end{array}$ & $\begin{array}{c}1.46 \\
(-0.41,2.97)\end{array}$ \\
\hline
\end{tabular}

Panel G: Respondents with household income less than $\$ 75,000$ who eat seaweed

\begin{tabular}{lcccc} 
Treatment 1 & 11.78 & 10.33 & 4.09 & 5.83 \\
Treatment 2 & $(10.29,13.93)$ & $(8.97,12.20)$ & $(1.95,5.97)$ & $(4.18,7.48)$ \\
& 9.07 & 8.40 & 5.83 & 4.85 \\
Control & $(8.18,10.20)$ & $(7.53,9.45)$ & $(4.77,6.87)$ & $(3.60,6.02)$ \\
& 7.98 & 6.85 & 1.94 & 4.03 \\
& $(7.31,8.77)$ & $(6.17,7.60)$ & $(0.20,3.41)$ & $(2.85,5.03)$ \\
\hline
\end{tabular}

Panel H: All respondents

\begin{tabular}{|c|c|c|c|c|}
\hline Treatment 1 & $\begin{array}{c}4.88 \\
(4.39,5.36)\end{array}$ & $\begin{array}{c}2.92 \\
(1.99,3.56)\end{array}$ & $\begin{array}{c}-5.59 \\
(-8.86,-3.38)\end{array}$ & $\begin{array}{c}-6.73 \\
(-10.28,-4.28)\end{array}$ \\
\hline Treatment 2 & $\begin{array}{c}5.48 \\
(5.15,5.77)\end{array}$ & $\begin{array}{c}3.43 \\
(2.77,3.93)\end{array}$ & $\begin{array}{c}-2.81 \\
(-4.85,-1.31)\end{array}$ & $\begin{array}{c}-1.99 \\
(-3.81,-0.66)\end{array}$ \\
\hline Control & $\begin{array}{c}4.19 \\
(3.69,4.58)\end{array}$ & $\begin{array}{c}3.01 \\
(2.29,3.54)\end{array}$ & $\begin{array}{c}-2.34 \\
(-4.29,-0.94)\end{array}$ & $\begin{array}{c}-3.65 \\
(-5.86,-2.02)\end{array}$ \\
\hline \multicolumn{5}{|c|}{ Panel I: Respondents who do not eat seaweed } \\
\hline Treatment 1 & $\begin{array}{c}1.79 \\
(-0.64,2.99)\end{array}$ & $\begin{array}{c}-0.19 \\
(-3.69,1.56)\end{array}$ & $\begin{array}{c}-16.00 \\
(-28.62,-9.45)\end{array}$ & $\begin{array}{c}-13.01 \\
(-23.96,-7.60)\end{array}$ \\
\hline Treatment 2 & $\begin{array}{c}3.25 \\
(1.81,4.05)\end{array}$ & $\begin{array}{c}-1.13 \\
(-4.51,0.70)\end{array}$ & $\begin{array}{c}-11.23 \\
(-19.58,-6.62)\end{array}$ & $\begin{array}{c}-8.66 \\
(-15.86,-4.84)\end{array}$ \\
\hline Control & $\begin{array}{c}0.55 \\
(-2.25,1.99)\end{array}$ & $\begin{array}{c}-0.26 \\
(-3.47,1.40)\end{array}$ & $\begin{array}{c}-9.70 \\
(-17.75,-5.46)\end{array}$ & $\begin{array}{c}-8.26 \\
(-15.77,-4.45)\end{array}$ \\
\hline
\end{tabular}

Notes: For panel A, the WTP estimates are calculated from the results from Appendix Table A2. For all other panels, the WTP estimates are calculated from equivalent results for subsamples of the entire set of responses. The top line of each cell is estimated mean WTP, and $95 \%$ confidence intervals (calculated using the Krinsky-Robb procedure) are shown in parentheses. 
Table 5. Estimated WTP for farm-raised clams, quahog littlenecks, raw, on the half shell (\$/doz.)

\begin{tabular}{|c|c|c|c|c|}
\hline & Connecticut & Rhode Island & Florida & Virginia \\
\hline \multicolumn{5}{|c|}{ Panel A: Respondents who eat shellfish } \\
\hline Treatment 1 & $\begin{array}{c}9.53 \\
(9.08,10.08)\end{array}$ & $\begin{array}{c}8.57 \\
(8.19,9.00)\end{array}$ & $\begin{array}{c}2.36 \\
(1.25,3.28)\end{array}$ & $\begin{array}{c}1.84 \\
(0.59,2.84)\end{array}$ \\
\hline Treatment 2 & $\begin{array}{c}9.88 \\
(9.41,10.45)\end{array}$ & $\begin{array}{c}9.10 \\
(8.70,9.56)\end{array}$ & $\begin{array}{c}3.22 \\
(2.30,4.01)\end{array}$ & $\begin{array}{c}3.33 \\
(2.40,4.10)\end{array}$ \\
\hline Control & $\begin{array}{c}9.47 \\
(9.03,10.02) \\
\end{array}$ & $\begin{array}{c}9.15 \\
(8.75,9.62) \\
\end{array}$ & $\begin{array}{c}3.75 \\
(2.91,4.46) \\
\end{array}$ & $\begin{array}{c}3.78 \\
(2.93,4.49) \\
\end{array}$ \\
\hline \multicolumn{5}{|c|}{ Panel B: Female respondents who eat shellfish } \\
\hline Treatment 1 & $\begin{array}{c}9.53 \\
(9.00,10.19)\end{array}$ & $\begin{array}{c}8.66 \\
(8.16,9.22)\end{array}$ & $\begin{array}{c}2.00 \\
(0.54,3.20)\end{array}$ & $\begin{array}{c}0.93 \\
(-0.79,2.37)\end{array}$ \\
\hline Treatment 2 & $\begin{array}{c}9.51 \\
(8.99,10.14)\end{array}$ & $\begin{array}{c}8.82 \\
(8.32,9.38)\end{array}$ & $\begin{array}{c}1.76 \\
(0.28,3.00)\end{array}$ & $\begin{array}{c}2.44 \\
(1.15,3.54)\end{array}$ \\
\hline Control & $\begin{array}{c}9.44 \\
(8.92,10.07)\end{array}$ & $\begin{array}{c}9.33 \\
(8.83,9.90)\end{array}$ & $\begin{array}{c}3.55 \\
(2.47,4.47)\end{array}$ & $\begin{array}{c}3.81 \\
(2.81,4.68)\end{array}$ \\
\hline
\end{tabular}

Panel C: Male respondents who eat shellfish

\begin{tabular}{lcccc} 
Treatment 1 & 9.54 & 8.44 & 2.58 & 2.38 \\
& $(8.97,10.23)$ & $(7.89,9.04)$ & $(1.24,3.74)$ & $(0.96,3.58)$ \\
Treatment 2 & 10.39 & 9.46 & 4.34 & 4.11 \\
& $(9.75,11.17)$ & $(8.87,10.14)$ & $(3.29,5.29)$ & $(3.01,5.09)$ \\
Control & 9.50 & 8.88 & 4.01 & 3.67 \\
& $(8.92,10.18)$ & $(8.31,9.50)$ & $(2.94,4.98)$ & $(2.51,4.69)$ \\
\hline
\end{tabular}

Panel D: College graduates who eat shellfish

\begin{tabular}{lcccc} 
Treatment 1 & 9.92 & 8.77 & 2.58 & 2.25 \\
& $(9.37,10.59)$ & $(8.28,9.32)$ & $(1.30,3.65)$ & $(0.92,3.38)$ \\
Treatment 2 & 10.11 & 9.42 & 3.18 & 3.72 \\
& $(9.56,10.78)$ & $(8.92,10.00)$ & $(2.04,4.15)$ & $(2.71,4.60)$ \\
Control & 9.16 & 8.95 & 3.12 & 3.74 \\
& $(8.68,9.74)$ & $(8.48,9.47)$ & $(2.02,4.06)$ & $(2.79,4.58)$ \\
\hline
\end{tabular}

Panel E: Respondents with no college degree who eat shellfish

\begin{tabular}{lcccc} 
Treatment 1 & 8.88 & 8.27 & 2.04 & 1.17 \\
& $(8.31,9.51)$ & $(7.70,8.88)$ & $(0.53,3.34)$ & $(-0.61,2.69)$ \\
Treatment 2 & 9.50 & 8.57 & 3.30 & 2.67 \\
& $(8.91,10.18)$ & $(7.98,9.19)$ & $(2.08,4.40)$ & $(1.27,3.89)$ \\
Control & 10.02 & 9.53 & 4.73 & 3.88 \\
& $(9.36,10.81)$ & $(8.89,10.25)$ & $(3.67,5.71)$ & $(2.64,4.98)$ \\
\hline
\end{tabular}




\begin{tabular}{|c|c|c|c|c|}
\hline Clams & Connecticut & Rhode Island & Florida & Virginia \\
\hline \multicolumn{5}{|c|}{ Panel F: Respondents with household income at least $\$ 75,000$ who eat shellfish } \\
\hline Treatment 1 & $\begin{array}{c}10.20 \\
(9.59,10.95)\end{array}$ & $\begin{array}{c}9.51 \\
(8.95,10.16)\end{array}$ & $\begin{array}{c}2.81 \\
(1.47,3.94)\end{array}$ & $\begin{array}{c}2.98 \\
(1.70,4.08)\end{array}$ \\
\hline Treatment 2 & $\begin{array}{c}10.08 \\
(9.50,10.78)\end{array}$ & $\begin{array}{c}9.39 \\
(8.85,10.00)\end{array}$ & $\begin{array}{c}2.60 \\
(1.26,3.75)\end{array}$ & $\begin{array}{c}3.33 \\
(2.18,4.34)\end{array}$ \\
\hline Control & $\begin{array}{c}9.29 \\
(8.77,9.91)\end{array}$ & $\begin{array}{c}9.27 \\
(8.76,9.85)\end{array}$ & $\begin{array}{c}2.17 \\
(0.76,3.37)\end{array}$ & $\begin{array}{c}3.63 \\
(2.57,4.55)\end{array}$ \\
\hline
\end{tabular}

Panel G: Respondents with household income less than $\$ 75,000$ who eat shellfish

\begin{tabular}{lcccc} 
Treatment 1 & 8.84 & 7.52 & 1.95 & 0.42 \\
& $(8.34,9.42)$ & $(6.99,8.06)$ & $(0.54,3.14)$ & $(-1.43,1.97)$ \\
Treatment 2 & 9.65 & 8.76 & 3.73 & 3.32 \\
& $(9.09,10.31)$ & $(8.23,9.35)$ & $(2.68,4.68)$ & $(2.15,4.33)$ \\
Control & 9.65 & 8.99 & 4.92 & 3.99 \\
& $(9.08,10.32)$ & $(8.44,9.60)$ & $(4.05,5.73)$ & $(2.93,4.91)$ \\
\hline
\end{tabular}

Panel H: All respondents

\begin{tabular}{lcccc} 
Treatment 1 & 8.20 & 7.25 & 0.61 & 1.38 \\
& $(7.91,8.54)$ & $(6.95,7.55)$ & $(-0.66,1.63)$ & $(0.28,2.28)$ \\
Treatment 2 & 8.60 & 7.74 & 2.21 & 1.96 \\
& $(8.29,8.97)$ & $(7.44,8.05)$ & $(1.27,2.99)$ & $(1.00,2.78)$ \\
Control & 7.74 & 7.34 & 2.36 & 2.41 \\
& $(7.47,8.03)$ & $(7.05,7.62)$ & $(1.50,3.09)$ & $(1.54,3.13)$ \\
\hline
\end{tabular}

Panel I: Respondents who do not eat shellfish

\begin{tabular}{lcccc} 
Treatment 1 & 4.88 & 3.98 & 0.05 & -1.79 \\
Treatment 2 & $(3.70,5.56)$ & $(2.15,4.97)$ & $(-3.65,2.08)$ & $(-6.73,0.88)$ \\
& 5.28 & 3.81 & -0.98 & 0.15 \\
Control & $(4.22,5.91)$ & $(1.83,4.87)$ & $(-5.47,1.49)$ & $(-3.78,2.20)$ \\
& 3.76 & 2.57 & 0.48 & 0.58 \\
& $(1.95,4.68)$ & $(-0.12,3.94)$ & $(-3.17,2.37)$ & $(-3.11,2.43)$ \\
\hline
\end{tabular}

Notes: For panel A, the WTP estimates are calculated from the results from Appendix Table A2. For all other panels, the WTP estimates are calculated from equivalent results for subsamples of the entire set of responses. The top line of each cell is estimated mean WTP, and $95 \%$ confidence intervals (calculated using the Krinsky-Robb procedure) are shown in parentheses. 
Table 6. Estimated WTP for farm-raised oysters, raw, on the half shell (\$/doz.)

\begin{tabular}{|c|c|c|c|c|}
\hline & Connecticut & Maine & Washington & Louisiana \\
\hline \multicolumn{5}{|c|}{ Panel A: Respondents who eat shellfish } \\
\hline Treatment 1 & $\begin{array}{c}13.79 \\
(13.44,14.14)\end{array}$ & $\begin{array}{c}12.52 \\
(12.12,12.89)\end{array}$ & $\begin{array}{c}8.61 \\
(7.48,9.45)\end{array}$ & $\begin{array}{c}7.43 \\
(6.03,8.46)\end{array}$ \\
\hline Treatment 2 & $\begin{array}{c}14.25 \\
(13.96,14.55)\end{array}$ & $\begin{array}{c}13.10 \\
(12.81,13.41)\end{array}$ & $\begin{array}{c}10.20 \\
(9.59,10.71)\end{array}$ & $\begin{array}{c}10.06 \\
(9.42,10.59)\end{array}$ \\
\hline Control & $\begin{array}{c}14.22 \\
(13.89,14.57) \\
\end{array}$ & $\begin{array}{c}13.22 \\
(12.87,13.57) \\
\end{array}$ & $\begin{array}{c}9.88 \\
(9.11,10.49) \\
\end{array}$ & $\begin{array}{c}9.36 \\
(8.50,10.05) \\
\end{array}$ \\
\hline \multicolumn{5}{|c|}{ Panel B: Female respondents who eat shellfish } \\
\hline Treatment 1 & $\begin{array}{c}13.44 \\
(12.96,13.91)\end{array}$ & $\begin{array}{c}12.54 \\
(12.03,13.03)\end{array}$ & $\begin{array}{c}8.07 \\
(6.68,9.13)\end{array}$ & $\begin{array}{c}7.03 \\
(5.44,8.27)\end{array}$ \\
\hline Treatment 2 & $\begin{array}{c}13.67 \\
(13.28,14.06)\end{array}$ & $\begin{array}{c}12.98 \\
(12.59,13.38)\end{array}$ & $\begin{array}{c}9.68 \\
(8.85,10.38)\end{array}$ & $\begin{array}{c}9.36 \\
(8.49,10.11)\end{array}$ \\
\hline Control & $\begin{array}{c}14.19 \\
(13.76,14.64)\end{array}$ & $\begin{array}{c}13.03 \\
(12.58,13.49)\end{array}$ & $\begin{array}{c}9.62 \\
(8.68,10.39)\end{array}$ & $\begin{array}{c}9.17 \\
(8.16,10.01)\end{array}$ \\
\hline
\end{tabular}

Panel C: Male respondents who eat shellfish

\begin{tabular}{|c|c|c|c|c|}
\hline Treatment 1 & $\begin{array}{c}14.18 \\
(13.66,14.72)\end{array}$ & $\begin{array}{c}12.45 \\
(11.86,13.00)\end{array}$ & $\begin{array}{c}9.21 \\
(8.03,10.16)\end{array}$ & $\begin{array}{c}7.94 \\
(6.45,9.12)\end{array}$ \\
\hline Treatment 2 & $\begin{array}{c}14.87 \\
(14.44,15.34)\end{array}$ & $\begin{array}{c}13.22 \\
(12.77,13.69)\end{array}$ & $\begin{array}{c}10.73 \\
(10.01,11.39)\end{array}$ & $\begin{array}{c}10.68 \\
(9.93,11.33)\end{array}$ \\
\hline Control & $\begin{array}{c}14.28 \\
(13.76,14.83) \\
\end{array}$ & $\begin{array}{c}13.45 \\
(12.92,14.00) \\
\end{array}$ & $\begin{array}{c}10.22 \\
(9.29,11.03)\end{array}$ & $\begin{array}{c}9.62 \\
(8.56,10.51) \\
\end{array}$ \\
\hline \multicolumn{5}{|c|}{ Panel D: College graduates who eat shellfish } \\
\hline Treatment 1 & $\begin{array}{c}13.93 \\
(13.48,14.38)\end{array}$ & $\begin{array}{c}12.92 \\
(12.45,13.38)\end{array}$ & $\begin{array}{c}9.16 \\
(8.04,10.03)\end{array}$ & $\begin{array}{c}7.50 \\
(6.03,8.64)\end{array}$ \\
\hline Treatment 2 & $\begin{array}{c}14.35 \\
(14.00,14.73)\end{array}$ & $\begin{array}{c}13.18 \\
(12.80,13.56)\end{array}$ & $\begin{array}{c}10.28 \\
(9.56,10.89)\end{array}$ & $\begin{array}{c}10.27 \\
(9.58,10.87)\end{array}$ \\
\hline Control & $\begin{array}{c}13.90 \\
(13.48,14.33) \\
\end{array}$ & $\begin{array}{c}13.34 \\
(12.92,13.78) \\
\end{array}$ & $\begin{array}{c}9.73 \\
(8.82,10.47) \\
\end{array}$ & $\begin{array}{c}9.40 \\
(8.46,10.18) \\
\end{array}$ \\
\hline \multicolumn{5}{|c|}{ Panel E: Respondents with no college degree who eat shellfish } \\
\hline Treatment 1 & $\begin{array}{c}13.58 \\
(13.01,14.14)\end{array}$ & $\begin{array}{c}11.84 \\
(11.16,12.45)\end{array}$ & $\begin{array}{c}7.60 \\
(6.02,8.87)\end{array}$ & $\begin{array}{c}7.36 \\
(5.71,8.68)\end{array}$ \\
\hline Treatment 2 & $\begin{array}{c}14.07 \\
(13.61,14.54)\end{array}$ & $\begin{array}{c}12.98 \\
(12.51,13.46)\end{array}$ & $\begin{array}{c}10.08 \\
(9.23,10.85)\end{array}$ & $\begin{array}{c}9.68 \\
(8.74,10.48)\end{array}$ \\
\hline Control & $\begin{array}{c}14.71 \\
(14.17,15.29)\end{array}$ & $\begin{array}{c}12.97 \\
(12.39,13.56) \\
\end{array}$ & $\begin{array}{c}10.11 \\
(9.12,10.97)\end{array}$ & $\begin{array}{c}9.28 \\
(8.09,10.27)\end{array}$ \\
\hline
\end{tabular}




\begin{tabular}{|c|c|c|c|c|}
\hline Oysters & Connecticut & Maine & Washington & Louisiana \\
\hline \multicolumn{5}{|c|}{ Panel F: Respondents with household income at least $\$ 75,000$ who eat shellfish } \\
\hline \multirow[t]{2}{*}{ Treatment 1} & 14.01 & 13.30 & 9.53 & 7.85 \\
\hline & $(13.53,14.51)$ & $(12.81,13.80)$ & $(8.44,10.38)$ & $(6.42,8.98)$ \\
\hline \multirow[t]{2}{*}{ Treatment 2} & 14.30 & 13.06 & 10.53 & 9.97 \\
\hline & $(13.92,14.71)$ & $(12.65,13.48)$ & $(9.82,11.14)$ & $(9.20,10.65)$ \\
\hline \multirow[t]{2}{*}{ Control } & 14.46 & 13.74 & 10.17 & 9.67 \\
\hline & $(13.99,14.97)$ & $(13.26,14.25)$ & $(9.25,10.94)$ & $(8.69,10.50)$ \\
\hline
\end{tabular}

Panel G: Respondents with household income less than $\$ 75,000$ who eat shellfish

\begin{tabular}{lcccc} 
Treatment 1 & 13.56 & 11.53 & 7.42 & 7.05 \\
& $(13.04,14.06)$ & $(10.86,12.10)$ & $(5.89,8.63)$ & $(5.40,8.34)$ \\
Treatment 2 & 14.18 & 13.15 & 9.76 & 10.14 \\
& $(13.77,14.62)$ & $(12.72,13.58)$ & $(8.90,10.51)$ & $(9.34,10.82)$ \\
Control & 13.98 & 12.63 & 9.54 & 9.00 \\
& $(13.52,14.47)$ & $(12.10,13.13)$ & $(8.56,10.36)$ & $(7.91,9.91)$ \\
\hline
\end{tabular}

Panel H: All respondents

\begin{tabular}{|c|c|c|c|c|}
\hline Treatment 1 & $\begin{array}{c}12.87 \\
(12.51,13.17)\end{array}$ & $\begin{array}{c}11.72 \\
(11.31,12.06)\end{array}$ & $\begin{array}{c}7.83 \\
(6.71,8.68)\end{array}$ & $\begin{array}{c}6.82 \\
(5.53,7.80)\end{array}$ \\
\hline Treatment 2 & $\begin{array}{c}13.50 \\
(13.25 .13 .74)\end{array}$ & $\begin{array}{c}12.37 \\
(12.10,12.62)\end{array}$ & $\begin{array}{c}9.57 \\
(8.95,10.08)\end{array}$ & $\begin{array}{c}9.29 \\
(8.64,9.84)\end{array}$ \\
\hline Control & $\begin{array}{c}12.86 \\
(12.53,13.15)\end{array}$ & $\begin{array}{c}11.90 \\
(11.53,12.22)\end{array}$ & $\begin{array}{c}8.60 \\
(7.71,9.30)\end{array}$ & $\begin{array}{c}8.14 \\
(7.18,8.89)\end{array}$ \\
\hline \multicolumn{5}{|c|}{ Panel I: Respondents who do not eat shellfish } \\
\hline Treatment 1 & $\begin{array}{c}10.68 \\
(9.12,11.51)\end{array}$ & $\begin{array}{c}10.10 \\
(8.57,10.93)\end{array}$ & $\begin{array}{c}6.42 \\
(2.91,8.29)\end{array}$ & $\begin{array}{c}6.36 \\
(2.93,8.23)\end{array}$ \\
\hline Treatment 2 & $\begin{array}{c}11.44 \\
(10.40,12.07)\end{array}$ & $\begin{array}{c}10.37 \\
(9.15,11.09)\end{array}$ & $\begin{array}{c}8.25 \\
(6.05,9.51)\end{array}$ & $\begin{array}{c}7.00 \\
(4.25,8.65)\end{array}$ \\
\hline Control & $\begin{array}{c}8.43 \\
(4.34,10.08)\end{array}$ & $\begin{array}{c}7.99 \\
(3.94,9.62)\end{array}$ & $\begin{array}{c}5.31 \\
(-0.99,7.81)\end{array}$ & $\begin{array}{c}5.17 \\
(-1.00,7.72)\end{array}$ \\
\hline
\end{tabular}

Notes: For panel A, the WTP estimates are calculated from the results from Appendix Table A2. For all other panels, the WTP estimates are calculated from equivalent results for subsamples of the entire set of responses. The top line of each cell is estimated mean WTP, and $95 \%$ confidence intervals (calculated using the Krinsky-Robb procedure) are shown in parentheses. 


\section{Web Appendix}

This appendix includes two tables reporting the results of conditional logit (CL) regressions. Appendix table A1 reports the results of four regressions, one for each of the four product types; appendix table A2 includes twelve separate regressions, one for each product type-treatment cell. The coefficients in appendix table A2 underly the WTP estimates reported in Panel A from tables 3 through 6 .

Appendix Table A1. Utility function parameter estimates

\begin{tabular}{|c|c|c|c|c|}
\hline & $\begin{array}{c}\text { Seaweed } \\
\text { noodles } \\
(1) \\
\end{array}$ & $\begin{array}{c}\text { Raw, fresh } \\
\text { seaweed } \\
\text { (2) }\end{array}$ & $\begin{array}{c}\text { Clams } \\
(3) \\
\end{array}$ & $\begin{array}{c}\text { Oysters } \\
\text { (4) }\end{array}$ \\
\hline Price & $\begin{array}{c}-0.319^{* * *} \\
(0.040)\end{array}$ & $\begin{array}{c}-0.434^{* * *} \\
(0.042)\end{array}$ & $\begin{array}{c}-0.386^{* * *} \\
(0.027)\end{array}$ & $\begin{array}{c}-0.369^{* * *} \\
(0.029)\end{array}$ \\
\hline Connecticut & $\begin{array}{l}4.729^{* * *} \\
(0.457)\end{array}$ & $\begin{array}{l}3.564^{* * *} \\
(0.280)\end{array}$ & $\begin{array}{c}3.658^{* * *} \\
(0.203)\end{array}$ & $\begin{array}{l}5.244^{* * *} \\
(0.398)\end{array}$ \\
\hline China & $\begin{array}{l}2.637^{* * *} \\
(0.464)\end{array}$ & $\begin{array}{l}1.282^{* * *} \\
(0.306)\end{array}$ & & \\
\hline Korea & $\begin{array}{l}2.841^{* * *} \\
(0.489)\end{array}$ & $\begin{array}{l}0.819^{* *} \\
(0.329)\end{array}$ & & \\
\hline Maine & $\begin{array}{l}4.404^{* * *} \\
(0.465)\end{array}$ & $\begin{array}{l}2.963^{* * *} \\
(0.273)\end{array}$ & & $\begin{array}{l}4.874^{* * *} \\
(0.382)\end{array}$ \\
\hline Rhode Island & & & $\begin{array}{l}3.533^{* * *} \\
(0.215)\end{array}$ & \\
\hline Virginia & & & $\begin{array}{l}1.460^{* * *} \\
(0.226)\end{array}$ & \\
\hline Florida & & & $\begin{array}{l}1.448^{* * *} \\
(0.227)\end{array}$ & \\
\hline Washington & & & & $\begin{array}{l}3.643^{* * *} \\
(0.383)\end{array}$ \\
\hline Louisiana & & & & $\begin{array}{l}3.454^{* * *} \\
(0.384)\end{array}$ \\
\hline Connecticut $\times$ Treatment 1 & $\begin{array}{c}1.053 \\
(0.666)\end{array}$ & $\begin{array}{l}-0.274 \\
(0.397)\end{array}$ & $\begin{array}{l}-0.119 \\
(0.289)\end{array}$ & $\begin{array}{l}-0.631 \\
(0.577)\end{array}$ \\
\hline Connecticut $\times$ Treatment 2 & $\begin{array}{c}0.996 \\
(0.647)\end{array}$ & $\begin{array}{c}0.457 \\
(0.393)\end{array}$ & $\begin{array}{c}0.120 \\
(0.285)\end{array}$ & $\begin{array}{c}0.780 \\
(0.566)\end{array}$ \\
\hline China $\times$ Treatment 1 & $\begin{array}{c}0.469 \\
(0.677)\end{array}$ & $\begin{array}{l}-0.729 \\
(0.447)\end{array}$ & & \\
\hline China $\times$ Treatment 2 & $\begin{array}{l}1.094^{*} \\
(0.653)\end{array}$ & $\begin{array}{c}0.270 \\
(0.437)\end{array}$ & & \\
\hline
\end{tabular}




\begin{tabular}{|c|c|c|c|c|}
\hline Korea $\times$ Treatment 1 & $\begin{array}{c}0.962 \\
(0.705)\end{array}$ & $\begin{array}{l}-0.465 \\
(0.474)\end{array}$ & & \\
\hline Korea $\times$ Treatment 2 & $\begin{array}{l}1.338^{*} \\
(0.687)\end{array}$ & $\begin{array}{l}1.349^{* * * *} \\
(0.440)\end{array}$ & & \\
\hline Maine $\times$ Treatment 1 & $\begin{array}{c}0.760 \\
(0.673)\end{array}$ & $\begin{array}{l}-0.343 \\
(0.389)\end{array}$ & & $\begin{array}{l}-0.685 \\
(0.550)\end{array}$ \\
\hline Maine $\times$ Treatment 2 & $\begin{array}{c}1.049 \\
(0.657)\end{array}$ & $\begin{array}{l}0.747^{*} \\
(0.387)\end{array}$ & & $\begin{array}{c}0.667 \\
(0.539)\end{array}$ \\
\hline Rhode Island $\times$ Treatment 1 & & & $\begin{array}{l}-0.348 \\
(0.305)\end{array}$ & \\
\hline Rhode Island $\times$ Treatment 2 & & & $\begin{array}{l}-0.052 \\
(0.301)\end{array}$ & \\
\hline Virginia $\times$ Treatment 1 & & & $\begin{array}{c}-0.778^{* *} \\
(0.334)\end{array}$ & \\
\hline Virginia $\times$ Treatment 2 & & & $\begin{array}{l}-0.187 \\
(0.319)\end{array}$ & \\
\hline Florida $\times$ Treatment 1 & & & $\begin{array}{c}-0.573^{*} \\
(0.330)\end{array}$ & \\
\hline Florida $\times$ Treatment 2 & & & $\begin{array}{l}-0.214 \\
(0.322)\end{array}$ & \\
\hline Washington $\times$ Treatment 1 & & & & $\begin{array}{l}-0.763 \\
(0.555)\end{array}$ \\
\hline Washington $\times$ Treatment 2 & & & & $\begin{array}{c}0.671 \\
(0.542)\end{array}$ \\
\hline Louisiana $\times$ Treatment 1 & & & & $\begin{array}{l}-0.969^{*} \\
(0.557)\end{array}$ \\
\hline Louisiana $\times$ Treatment 2 & & & & $\begin{array}{c}0.799 \\
(0.543)\end{array}$ \\
\hline Number of observations & 12040 & 12040 & 27660 & 27660 \\
\hline Log-likelihood function & -2999.2796 & -2881.0357 & -6693.7648 & -7699.1046 \\
\hline Pseudo-R ${ }^{2}$ & 0.2261 & 0.2566 & 0.2482 & 0.1353 \\
\hline
\end{tabular}

Notes: These regressions include only respondents who indicated that they ate seaweed (columns 1 and 2) or shellfish (columns 3 and 4). Standard errors in parentheses. ${ }^{* * *},{ }^{* *}$, and ${ }^{*}$ indicate significance at the $\mathrm{p}<0.01,0.05$, and 0.1 levels, respectively. 
Appendix Table A2. Utility function parameter estimates for respondents who eat seaweed/shellfish (3 separate regressions for each product type).

(1)

(3)

Treatment 1

Treatment 2

Control

Farmed seaweed noodles

Connecticut

$5.782^{* * *}$

$5.725^{* * *}$

$4.729^{* * *}$

$(0.485)$

(0.459)

(0.457)

China

$3.106^{* * *}$

$3.731^{* * *}$

$2.637^{* * *}$

(0.493)

$(0.460)$

(0.464)

Korea

$3.803^{* * *}$

$4.178^{* * *}$

$2.841^{* * *}$

(0.508)

(0.482)

(0.489)

Maine

$5.164^{* * *}$

$5.453^{* * *}$

$4.404^{* * *}$

(0.486)

(0.463)

(0.465)

Price

$-0.378^{* * *}$

$-0.380^{* * *}$

$-0.319^{* * *}$

(0.042)

(0.040)

(0.040)

Number of observations

4000

4000

4040

Log-likelihood function

$-946.13258$

$-1017.5108$

$-1035.6362$

Pseudo-R ${ }^{2}$

0.2652

0.2097

0.2036

Farmed raw, fresh seaweed

Connecticut

$3.290 * * *$

(0.281)

China

$0.553^{*}$

(0.326)

Korea

0.354

(0.341)

Maine

Price

Number of observations

Log-likelihood function

Pseudo-R ${ }^{2}$
$2.621 * * *$

(0.278)

$-0.347^{* * *}$

(0.042)

4000

$-932.71763$

0.2756
$4.021 * * *$

(0.275)

$1.552 * * *$

(0.312)

$2.168 * * *$

(0.293)

$3.711^{* * *}$

(0.275)

$-0.405 * * *$

(0.040)

4000

$-966.85069$

0.2491
$3.564 * * *$

(0.280)

$1.282 * * *$

(0.306)

$0.819 * *$

(0.329)

$2.963 * * *$

(0.273)

$-0.434 * * *$

(0.042)

4040

$-981.4674$

0.2453

Farm-raised clams, quahog littlenecks, raw, on the half shell

Connecticut

Rhode Island

Virginia
$3.539 * * *$

(0.206)

$3.185 * * *$

$(0.216)$

$0.682 * * *$

(0.246)
$3.779 * * *$

(0.199)

$3.481 * * *$

(0.210)

$1.272 * * *$

(0.226)
$3.658 * * *$

$(0.203)$

$3.533 * * *$

$(0.215)$

$1.460 * * *$

$(0.226)$ 


\begin{tabular}{|c|c|c|c|}
\hline Florida & $\begin{array}{c}0.875 * * * \\
(0.239)\end{array}$ & $\begin{array}{c}1.234 * * * \\
(0.228)\end{array}$ & $\begin{array}{c}1.448 * * * \\
(0.227)\end{array}$ \\
\hline Price & $\begin{array}{c}-0.372 * * * \\
(0.028)\end{array}$ & $\begin{array}{c}-0.383 * * * \\
(0.027)\end{array}$ & $\begin{array}{c}-0.386 * * * \\
(0.027)\end{array}$ \\
\hline Number of observations & 9120 & 9480 & 9060 \\
\hline Log-likelihood function & -2157.8217 & -2269.4868 & -2266.4564 \\
\hline Pseudo- $\mathrm{R}^{2}$ & 0.2650 & 0.2563 & 0.2228 \\
\hline \multicolumn{4}{|c|}{ Farm-raised oysters, raw, on the half shell } \\
\hline Connecticut & $\begin{array}{c}4.613 * * * \\
(0.418)\end{array}$ & $\begin{array}{c}6.024 * * * \\
(0.402)\end{array}$ & $\begin{array}{c}5.244 * * * \\
(0.398)\end{array}$ \\
\hline Washington & $\begin{array}{c}2.880 * * * \\
(0.402)\end{array}$ & $\begin{array}{c}4.314 * * * \\
(0.384)\end{array}$ & $\begin{array}{c}3.644 * * * \\
(0.383)\end{array}$ \\
\hline Louisiana & $\begin{array}{c}2.484 * * * \\
(0.404)\end{array}$ & $\begin{array}{c}4.252 * * * \\
(0.384)\end{array}$ & $\begin{array}{c}3.454 * * * \\
(0.384)\end{array}$ \\
\hline Maine & $\begin{array}{c}4.189 * * * \\
(0.396)\end{array}$ & $\begin{array}{c}5.541 * * * \\
(0.381)\end{array}$ & $\begin{array}{c}4.874 * * * \\
(0.382)\end{array}$ \\
\hline Price & $\begin{array}{c}-0.334 * * * \\
(0.030)\end{array}$ & $\begin{array}{c}-0.429 * * * \\
(0.029)\end{array}$ & $\begin{array}{c}-0.369 * * * \\
(0.029)\end{array}$ \\
\hline Number of observations & 9120 & 9480 & 9060 \\
\hline Log-likelihood function & -2497.8986 & -2652.4795 & -2548.7264 \\
\hline Pseudo-R ${ }^{2}$ & 0.1491 & 0.1308 & 0.1260 \\
\hline
\end{tabular}

